\title{
Study on Local Applied Undergraduate Logistics Management Entrepreneurship Cultivation
}

\author{
(SUBMITTED BUT NOT PRESENTED) \\ FENG Lipeng \\ College of Economy Management, \\ Chongqing University of Arts and Sciences, Chongqing Yongchuan \\ P.R.China 402160; \\ e-mail:michelleflp@163.com
}

\begin{abstract}
From the aspect of the current situation of entrepreneurship cultivation for higher logistics management major students, this paper describes issues in the entrepreneurship cultivation mode and achievements in practical reform with the characteristics of local application Undergraduate. It sorts out the basic ideas of entrepreneurship cultivation mode reform in local application Undergraduate. This paper gives a detailed explanation from the entrepreneurship cultivation programs, vocational qualification certificate, certification teaching staff, and teaching contents. Finally, in the implementation of the "course and card integration" which is the representative of the personnel training reform, the paper gives mode additional recommendations.
\end{abstract}

Keywords—-local applied undergraduate;

entrepreneurship cultivation mode; class and card integration

\section{ANALYSIS ON THE PRESENT SITUATION OF LOGISTICS MANAGEMENT AND LOGISTICS INDUSTRY}

Logistics management is a new emerging professional major in the economics and management theory. Both qualitative and quantitative analysis methods are required. The technology is based on system engineering. The goal is training applied talents and it is a very practical professional.

China's logistics development is very fast. There is a huge entrepreneurial space and great demand for applied talents. It is estimated that in 2014, total social logistics costs accounted for GDP the ratio of $18.9 \%$, which is two times higher than in developed countries. It means each one percentage point lower this ratio is equivalent to the creation of the economic value of RMB300 billion. Each 6 percentage point increase in the logistics industry can drive the increase of one percentage point of service industry. At present, China's logistics industry employees are about 20 million. Each one percentage point increase in the logistics industry can add 100000 jobs.

Therefore, under this larger context, it is in line with the development of the country strategy and school talent to research logistics management professional applications talents based with entrepreneurial orientation. To logistics management of Chongqing university of arts and sciences, it has important practical significance in fostering further promotion on professional teaching reform, improving entrepreneurial training program and applied talents, and improving their employment and entrepreneurship. And it also has an important demonstration effect for the reform of training mode and path of logistics talents in university and in china.

\section{ANALYSIS ON THE PRESENT SITUATION OF ENTREPRENEURSHIP EDUCATION}

In China, the number of college graduates is increasing in recent years, which let graduates in universities are facing severe employment pressures. To reduce the employment pressure, the government, universities and communities encourage students to start their own business. The "entrepreneurship" has become an important policy to solve the employment problems of college students.

Entrepreneurship education is a new trend in the development of the reform on higher education in China. The Ministry of education in August 2012 also issued "general undergraduate school entrepreneurship education teaching basic requirements" document. It not only further clarifies the direction of entrepreneurship education, but also provides a new topic with the applied undergraduate colleges entrepreneurship education and curriculum integration. In recent years, Logistics Management application-oriented is under a state of vigorous development. It needs deep rational thinking to the mode of entrepreneurship education and logistics professional education. Entrepreneurship education is currently the new concept of higher education, rather than education mode. Entrepreneurship education goal is consistent with professional education that is to cultivate high-quality talents with innovative spirit and practical ability. Therefore in higher education there is a big intersection, and interact, complement each other.

At present, the research about the logistics discipline of entrepreneurship education is rarely in China. With the interdisciplinary characteristics of logistics discipline practice, Hu Yunfeng (2011) studied entrepreneurship education system of professional logistics management from the aspects of the construction of practical teaching system, system construction of ideological education, professional logistics management entrepreneurship education system. He advocated "learning" and "doing" as the main contents of the logistics discipline of entrepreneurship education. Ren Lifang (2012) explored the entrepreneurship education mode of integration on logistics management professional employment education and entrepreneurship education, and further put forward the construction of "double type" entrepreneurship teachers. On the one hand, it strengthened the cultivation of teachers' professional logistics management, on the 
other hand it paid attention to attract entrepreneurs as parttime teachers. It also reduced students' business risk and improves business confidence (Ren Lifang et al,2013). Yang Jun (2014) discussed how to make entrepreneurship education into higher vocational logistics professional theory and practice. Tang Xiaohong (2012) actively set up entrepreneurship courses, built a business platform and realized the implantation of entrepreneurship courses teaching. Zou Hualing (2010) put forward the entrepreneurship training into logistics professional training, and explored how to carry out the logistics specialty in Higher Vocational entrepreneurship training. Li Yiliang (2011) studied the cultivation of entrepreneurial students majoring in logistics management. Liu Xiaoming (2012) took logistics management as an example to explore the integration of entrepreneurship education and employment education curriculum system. Zhao Lindu (2013) pointed out the importance of entrepreneurship education not only lied in the fact that it is a process of lifelong learning, but also the driving force of entrepreneurship in China.

But China's university graduates entrepreneurship ratio has been hovering around $2 \%$ which is far lower than the proportion in western developed countries up to $20 \%$ $30 \%$ of the college students. Therefore, an important breakthrough in how to guide and promote college students' entrepreneurship has become the reality of the problem to solve the difficult employment of college students. Study on the macro level is mainly from the perspective of college, society, government and so on. The contents are to discuss the entrepreneurship education, entrepreneurial environment and other issues. On the micro level the content is mostly for college students' entrepreneurship education connotation, approach, mode, entrepreneurship education and employment, entrepreneurship education curriculum design, entrepreneurship education evaluation system. It is rare on how to put the entrepreneurship education and professional education research literature fusion. The paper makes a tentative study on this issue based on Logistics Management Specialty in applied Higher College as an example.

\section{THE FUSION WAY OF ENTREPRENEURSHIP EDUCATION CONTENT AND LOGISTICS EDUCATION}

In general, scholars put forward different views from different perspectives and form a distinctive China logistics discipline of entrepreneurship education research. Logistics management is different in nature with other management majors. It is interdisciplinary, and has highly application technology. The graduates require strong practical abilities. Now the logistics industry in China is in the integration and development period. It provides a rare historical opportunity for the graduates in the field entrepreneurship. So graduates entrepreneurial spirit and practical ability have become important condition on logistics management teaching and graduates employment. The establishment and implementation of Entrepreneurship teaching system and teaching goals are the focus and difficulty of the current logistics professional teaching reform.
The Target of applications Logistics personnel training is to cultivate and improve students' innovative spirit and practical ability, to strengthen the basic knowledge and practical skills and strive to cultivate high-quality talents with strong practical ability on logistics management planning and design. In the specific integration way of entrepreneurship education and professional education, the two should integrate from followings.

\section{A. The level of logistics professional curriculum theory}

There are a lot of logistics Management Specialty theoretical courses. We can penetrate entrepreneurship education ideas, methods and skills in theoretical courses, and focus on training in the following three areas of expertise entrepreneurial capacity.

\section{1) the ability of setting up logistics enterprises}

The theory courses of applied logistics management include seven functions that are transport, storage and distribution etc. Theses professional content is necessarily with the logistics enterprise operation mode, organizational structure, business processes and related knowledge. For college students with entrepreneurship, logistics, transportation, delivery, distribution and other enterprises are likely to be a good choice of entrepreneurship. It is necessary to understand the knowledge and methods of risk aversion in the future business.

\section{2) Improve logistics service ability}

The logistics industry is a typical production service industry. The customer relationship is complex because the upstream and downstream involve a large number of customers. Essential knowledge of customer service is important to engage in logistics industry and entrepreneurship. So it is necessary to let students master logistics customer relationship management courses. Students need specific customer knowledge, such as customer retention, core customer management, customer satisfaction and loyalty, etc. All these will provide higher customer management skills for future business.

\section{3) Increase logistics innovation.}

China's logistics industry is very competitive, and mostly are the price wars. In order to stand out in this industry, we must take service innovation, provide valueadded services. To Applied logistics majors, their training methods and objectives determine it must have a strong professional ability to innovate. If you can focus on teaching professional theory to guide their professional creative thinking, improve the thinking ability of the logistics service innovation, then that they find a new niche market will be possible.

\section{B. The level of Logistics Simulation AND professional practice Course}

There are many simulation programs in Logistics Management application-oriented including ERP, SCM, and CRM. Entrepreneurship is a very strong practical activity. The accumulation of entrepreneurial knowledge and the improvement of entrepreneurial ability require practice to test and practice. Therefore it can play a 
multiplier teaching effectiveness to integrate entrepreneurship education with logistics management professional organically. We can improve the probability of future success. This is mainly reflected in the following professional practice.

\section{1) Logistics enterprise personnel Public lecture.}

It includes organizing various entrepreneurial class lectures, reports and discussions. We can let students know the problems and difficulties by inviting entrepreneurs share the hardships course, success or failure. Students can open the entrepreneurial passion and make it beneficial enlightenment through the communication between entrepreneurs and students.

\section{2) To visit the logistics enterprises.}

Students need to see and hear more, and then there are certain perceptual knowledge and ideological sentiment on entrepreneurial activity. Logistics management professional students have to go to the enterprise to understand practice course. By visiting different logistics enterprises, students can have a more intuitive understanding of different business. All these will provide more reference for future interest in entrepreneurial choice.

3) To Participate in various entrepreneurship competitions.

With the national emphasis on entrepreneurship education, a variety of business competition began to attract the attention of college students. The "Challenge Cup" entrepreneurship competition is the most wellknown entrepreneurship competition. Universities across the country have organized professional team under the guidance of teachers actively involved. In recent years, various logistics competitions are also booming. Regardless of the final ranking, preparing the entire game, direction and implementation of processes will improve the ability of college students.

\section{4) To write the graduation thesis.}

This is a very important practical aspect to applicationoriented professional logistics management. Students need theoretical study and practical exploration within a semester to issues which they are interested in. Finally they need complete graduation thesis with the full combination of theory and practice. In the process, students will go into the logistics industry quite often, discover and ponder the current hot issues, and propose new solutions and new ideas. This is the important process to examine the business operations of entrepreneurs and timely amendment to improve the drawbacks of experiences and lessons.

\section{5) Business internship.}

The application of undergraduate logistics management will be arranged in this part of the practice course in the four stages. In addition students will use summer vacation to do some short-term job practice. The internship students are with their own future occupation planning, and select related enterprises. All these accumulated valuable experience for the future entrepreneurial activities. In this stage, students fully integrated into the enterprises. This makes not only final assessment to their business plans, feasibility of its implementation, but also for the future accumulation of certain business contacts.

Universities Entrepreneurship education is a systematic project, and it can not accomplish at one stroke. Application oriented focus on the "application". Logistics management, as a relatively new type of cross-disciplinary, become more prominent its practicality in the content, links, methods, systems. In logistics curriculum system construction and exploration, how to better integrate entrepreneurship education which foster an innovative spirit and entrepreneurial qualities of high-quality logistics personnel is an important issue .

\section{ANALYSIS ON THE PRESENT SITUATION OF "COURSE AND CARD INTEGRATION"}

With the strategy formulation of "western trade logistics highland" and the construction of manufacturing base of world-class IT giant in Chongqing, it shows great potential for development in outgoing logistics, introverted logistics, and supply chain logistics. Meanwhile, relevant departments present "in the shortest possible time to train more logistics entrepreneurship" to university in Chongqing. In this context, this paper from the perspective of "class card integration" discusses logistics management entrepreneurship cultivation problems with a full range. The "class card integration" in higher vocational education level, has done some research, and many vocational colleges also have many attempts in "double certificate" teaching mode. However, it is still in the beginning stages for many local application undergraduate colleges in "how to better serve the local economic construction", especially in "undergraduatelevel training model on how to best meet the practical requirements to the quality of entrepreneurship for the economic construction". In this article, the author intends to elaborate local application undergraduate training issues in the reform and practical results that have achieved in Chongqing University of Arts and science, and puts forward mode additional recommendations in the implementation of "Course and card integration".

The so-called "course and card integration", in many vocational colleges, also known as "double certificates teaching", refers to the corresponding courses and professional research. Curriculum materials, teaching content and textual content are linked each other. Schools' goal is that students can directly participate in the relevant professional certification exams after the completion of the course. Of course, the vocational qualification certificate pass rate is important criterion on testing the quality of classroom teaching, even the only criteria.

"Class card integration" training model in higher vocational college in China has gone through many years. In 2004, the Ministry of Education put forward "opinions on the Employment Orientation on higher vocational education reform". Then "double certificates" systems would be the primary means on the reform of entrepreneurship cultivation mode. The Ministry of Education in vocational education also presented in 2006: to expand the proportion of professional qualification 
certificates, while obtaining certification at the same time. Not only such, local education administrative departments should also take the initiative to strengthen cooperation with relevant departments and industry to jointly develop the vocational qualification system of higher education.

Currently, the reform has achieved significant results in the "work-integrated learning" "integrated teaching in speaking, training, testing" "project teaching" "Process Assessment" etc,

\section{THE BASIC IDEAS OF REFORM IN APPLICATION LOGISTICS UNDERGRADUATE ENTREPRENEURSHIP TEACHING}

Undoubtedly, what higher vocational colleges have achieved has great reference value for application undergraduate research training model. But this can not be completely used, it has different level orientation. For example, many vocational colleges make "class card integration" into the other extreme, look on the "higher vocational education" as "vocational training". It only pays attention to the current employ-ability of students, while ignores the sustainable development. Since a few months of training institutions in society can train skilled workers, then why the students waste up to 3 years or more in school time?

A prerequisite for personnel training mode in successful implementation of the "class card integration" is to aim at their own level of personnel training, to establish the appropriate standard of professional positions, career research project. All are footholds for future survival to undergraduate university which has a longer duration of study. Therefore, ChongQing University of arts and sciences takes the initiative to the entrepreneurship market and conduct research to dozens of enterprises. Our logistic entrepreneurship localization by discussing with industry experts is: a comprehensive physical and moral development of application-oriented logistics personnel with the ability to adapt to a socialist market economy and competitiveness, with economics, management and information technology knowledge, with innovative spirit and practical ability, familiar with the transportation, storage, processing, distribution, information services etc, with logistics management theories and methods, adapting to information technology, international need.

In Figure 1, we try to create the basic reform ideas of the application undergraduate entrepreneurship training model. That is, school teaching should closely relate with the market demand. To research students' market value, we put the comprehensive capacity of graduates, professional core competencies and ability into personnel training program. We have a clear positioning on the professional personnel training, training specifications and standards on testing personnel quality with different core curriculum and teaching module.

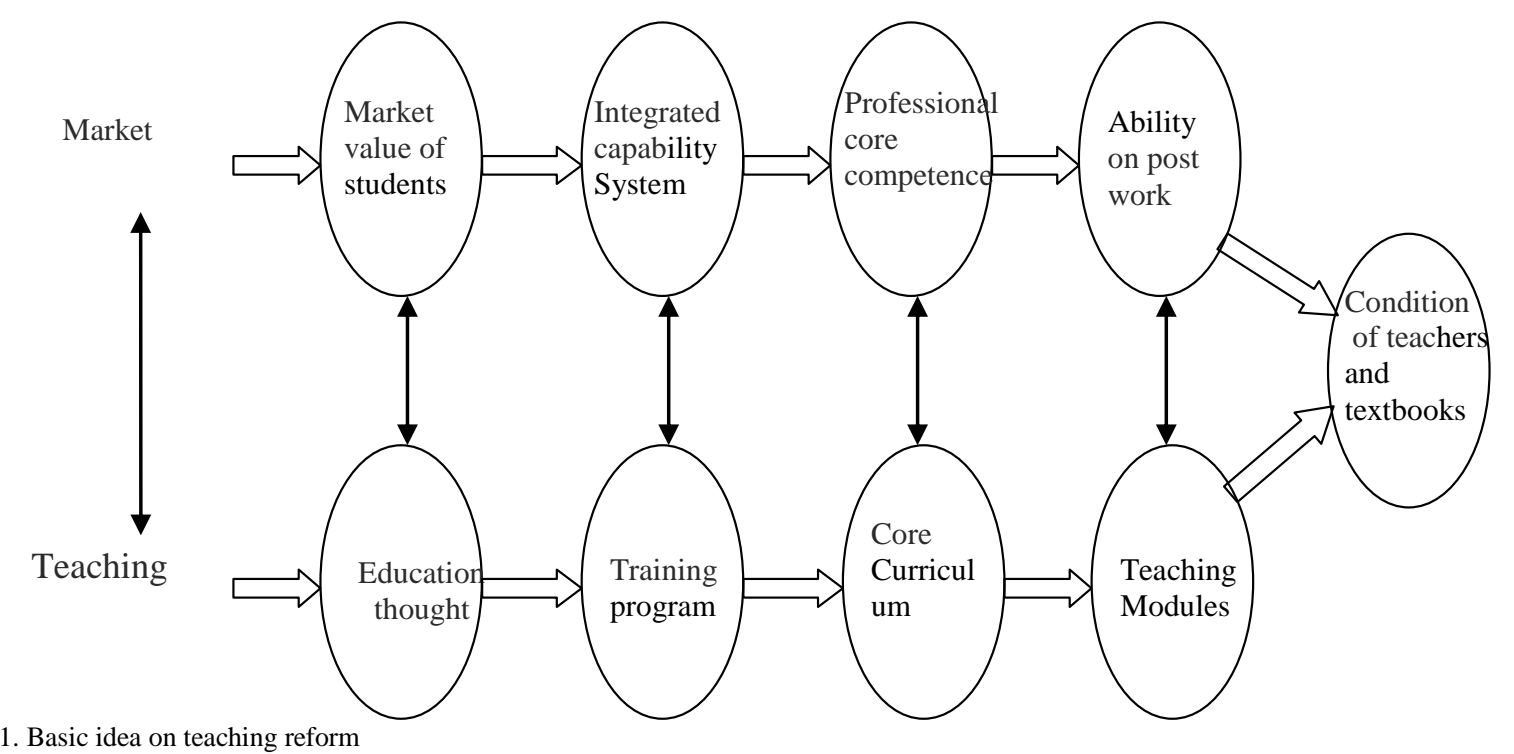

Figure.1. Basic idea on teaching reform

\section{REFORM INITIATIVES OF "CLASS CARD INTEGRATION" IN LOGISTICS MANAGEMENT MAJOR}

First need to emphasize, that talent cultivation in applied undergraduate can not simply rely on "class card integration", but rather seek a integration of "class card integration" "laboratory teaching" "school-enterprise cooperation" and other means. The author summaries "class card integration" only, because of limited space.

\section{A. try to respond to the real needs of professional positions in the training program design}

The designing of Entrepreneurship cultivation programs is often behind closed doors and away from the real world career job requirements in traditional undergraduate education. ChongQing University of arts and sciences had strongly strengthened the contact and cooperation with the enterprise to avoid subjective. For example, they hired a number of experts in the logistics industry in Chongqing region as a part-time professor, 
asked them to sum up logistics post group which graduates may be engaged in future, and then analyzed the process and tasks for each level of work, and then extracted professional quality, professional ability and expertise, and finally with classroom teachers to determine professional courses and professional qualification certificates students need.

\section{B. Pay attention to practical and authority in selecting professional certificate}

It is not simple for students to identify the professional qualification certificate. At present, China's logistics industry still has not professional positions standards. Accordingly, the society's professional qualification certificate examinations and training institutions can be described as mixed. There are many certification bodies operating simultaneously the same professional testing. Some also are lack of authority and have not high degree of recognition. The examinations through the motions and mercenary are also commonplace.

In order to find Logistics Vocational Qualification Certificate which is most fit for our students and has social recognition. The author grasped lot of in formations in several ways:

First, communicating with education peer at home and abroad, such as to Hefei university studying, to consult purchasing managers' professional qualification certificate with professor in American Shenandoah University;

Second, sorting on the recognition of certificates issued by investing domestic and foreign logistics companies;

Third is a horizontal inspection on national certification bodies.

So far, the training of logistics-related qualifications in ChongQing University of arts and sciences includes "assistant logistics", "foreign trade logistics", "foreign trade documents" and so on.

\section{Focus on training teachers "Double Quality"}

Although all universities are calling for the introduction of the backbone to school to teach business, an unavoidable problem is the backbone of these enterprises is unlikely to find time and energy to teaching. Even though some universities employ the backbone for part-time teachers, they just have one or two classes a semester, or do only one or two lectures. Combined with part-time teachers are still some problems in general in the classroom organization, teaching methods, verbal ability, the teaching effect are often not satisfying.

Therefore, the same with similar universities, fulltime teachers are the main professional teaching team in ChongQing University of arts and sciences. The vast majority of these teachers are from the school to the school and lack of experience in general. In order to enhance the "Double Quality", ChongQing University of arts and sciences selected the backbone of teachers to participate in training teaching methods, in addition to arrangement teachers to the enterprise in summer and winter holiday including vocational qualification examination organized by institutions and organizations "Trainer" training. With the rich experience of professional teachers, higher teaching level, academic titles enhancing, their classroom teaching and research training are no longer blindly indoctrinated.

\section{D. let students having better sense of direction by determining each module position}

In the "class card fusion" trend, the subject system also needs to inject "professionalism". For example, professional teachers should know "post group" or "job chain". These are taught in the freshmen, so that students know what kind of jobs most likely future, and learn to be more purpose.

\section{E. Keep learning enthusiasm by relating professional qualification examinations with daily teaching}

An entry job as in logistics industry is hard. How to motivate students' professional identity and pride is very important. ChongQing University of arts and sciences try to do the following in stimulating enthusiasm:

First, the school invested more than 20 million for acquisition of practical operation simulation and certification exam software, in order to facilitate students gain knowledge and skills, which is at the forefront of Chongqing Municipality;

Second, most important competition module of "Logistics Management Skills Competition" is qualification examination content, in order to promote the enthusiasm of students in examinations;

Third, the school also sets up a specialized professional research scholarships, and awards students who gets high performance in the professional research, thereby promotes research initiative.

\section{CONCLUSIONS}

With students attending various vocational qualification examinations each year, we continue to identify problems, analyze and solve problems and promote the "class card integration" course system. Recent years, teaching system in "class card integration" has made some achievements. Through this method of teaching practice, the pass rate of vocational research has a different rate increase to logistics management students. During the teaching reform on "class card integration", we also notice some discordant note, such as the existence of some schools offering exam focus; even deliberately give answers and other phenomena, in other words, buying occupational qualification. We need to reflect the original intention of teaching reform. It is "creating real workplace competitiveness". Teaching reform in the application undergraduate is a system work, "class card integration" needs other reform measures and stands the test of practice. 
Chinese logistics entrepreneurship education system construction is a long-term, gradual process. It is a complicated system engineering, needs all aspects of government, society, school, family attention, and gives them support and attention. In the social needs and student demand driven, China logistics discipline of entrepreneurship education should be aimed at establish entrepreneurial awareness, improve entrepreneurial psychological and business knowledge, expand the entrepreneurial ability, and establish the policy support system, teaching staff service system and cultural environment support. The aim is to promote China Logistics subject of entrepreneurship education for sustainable development.

Further, education colleges and universities require raise awareness on the importance of practice, and actively expand the business practice channels. It also need convert it with colleges, enterprises, knowledge, combined with public welfare activities. We should create more opportunities for students to practice with a variety of means. To timely study and solve business practice Students in the new situation require strengthen the construction of entrepreneurship education system to make it more responsive to the situation. At the same time, we should pay attention to the implementation of student business plan and focus on the growth of entrepreneurial organization. Self-employment is particularly concerned about the late development of students.

\section{REFERENCES}

[1] Gordon Tullock, An Economic Analysis of the rent-seeking activities [J]. Southwestern University of Finance Press, 1999:7

[2] Zhang an Ping, Fang Hua. Based on career-oriented "class card integration" Training and Practice Patterns and Reflections [J]. Journal of Chinese higher education research. 2008.11 58-59(in Chinese)

[3] huang dong mei, tang tian. Based on the "class card integration" Training and Practice Patterns Study [J]. Vocational education research. 2010.6 68-69(in Chinese)

[4] Tianjun Fang. International Trade Professional "class card integration," applied Talent Training [J]. journal of operators and managers 2010.16,83(in Chinese)

[5] FENG lipeng, On the Development of Logistics through Interpretation of Logistics Planning [J]. academic journal of Chongqing university of arts and sciences.,2010 volume 29, pp9092(in Chinese)

[6] WEI Wen-jing. The Experimental Teaching Mode for the Cultivation of Economics and Management Talents $[\mathrm{J}]$. research and Exploration in Laboratory,2012(5) : 186-190.

[7] QI Ye- guo. University Innovation Talent Deep Thought Culture System R reform [ J ]. China Higher Education,2010(17):1619.

[8] YUAN Xun, GUO Hui, QIN Chang- ming. Exploration and Practice on Constructing System of Applied Talents' Cultivation and Practice Teaching in Local Universities[J].Experimental Technology and Management,2011,28(8):1- 4.

[9] Fan, Xiaoqing; Qi, Yu; Gao, Fan. The countermeasure and suggestion of the cultivation and development of the contemporary Ningbo businessmen's entrepreneurship and innovation [Z], ICAMS, 2010(2):113-115.

[10] Ye, Suwen, Yang, Jun. Study on modularized synthetic cultivation system of technology entrepreneurship education of technology entrepreneurship education [Z], MASS 2011:106-112.
[11] Fan, Xiaoqing; Qi, Yu; Gao, Fan An exploration of the cultivation mode of innovation and entrepreneurship education with modern information technology for statistics students[Z], ICEMMS, 2010:20-24,

[12] Li, Yong; Huang, He; Zhou, Xuexin. An exploration of the cultivation mode of innovation and entrepreneurship thinking for energy statistical professional students [Z], CSEE 2011(4): 465469.

[13] Li, Yong. "Innovation and entrepreneurship" talents cultivation system construction in economic management [J], Energy Education Science and Technology, 2013(31):261-264.

[14] Tian, Xueying. Research and exploration on the cultivating model of the innovation and entrepreneurship of information specialty in university [J]. BioTechnology, 2014(8):2514-2519.

[15] Lv, Jia; Liu, Jianfeng Study on the theoretical framework of the mode applicable to cultivation of inter-disciplinary innovative talents for information-based entrepreneurship[J], Transactions on Information and Communication Technologies, 2014(1): 1147 1153 .

[16] Sun, Delin.The rises of innovative enterprise's entrepreneurship [J] International Symposium on Knowledge Acquisition and Modeling, 2009(1):216-219.

[17] Tao, Guo; Qiuying, Yu. Innovative and entrepreneurship education in underdeveloped Western regions of China[J], WiCOM, 2008(2):169-173.

[18] Lu, Chang-Jiang; Feng, Yan; Chen, De-Wen Analysis of the guiding role of skill factor model in college talent entrepreneurship: 19th International Conference on Industrial Engineering and Engineering Management[J],Assistive Technology of Industrial Engineering, 2013:1023-1029.

[19] Bai, Yunli; Miao, Miao; Li, Yaowei. Entrepreneurial motivation and entrepreneurship career intention: Case at a Malaysian public university[J],Computer Modeling and New Technologies, 2014:279-282.

[20] Kim-Soon, Ng; Ahmad, Abdul Rahman; Ibrahim, Nurul Nadia Research on entrepreneurship education based on e-commerce[Z] Proceedings of the 24th International Business Information Management Association Conference, 2014:1001-1011.

[21] Zunfeng, Liu; Chunling, Zhang. Exploration and practice of entrepreneurship training model in the innovation experimental area for information professional[J],ICCIC 2011(5):381-388.

[22] Lv, Jia; Liu, Jianfeng Study on evolutionary path of university students' entrepreneurship training[J], Information and Communication Technology for Education, 2014(1):1139-1145.

[23] Yang, Daojian; Zhao, Xicang Study and practice on training scheme of university students' entrepreneurship ability[J] Mathematical Problems in Engineering, 2014:18-23.

[24] Guojin, Chen Integrating entrepreneurship and innovation into an engineering curriculum through service learning and the libera arts: Communications in Computer and Information Science[J], ICCIC 2011(3):299-304.

[25] Wikoff, Katherine Hennessey; Carriere, Michael Hoge Mode for cultivation of diversified informationized innovative and entrepreneurial talents research and practice[J], ASEE, 2012:305310.

[26] Sun, De Lin; Zhang, Jian; Lee, Jiao; Research on cultivation mechanism of enterprise ability for undergraduates on the view of employment[J],Applied Mechanics and Materials, 2014: 1624 1627

[27] Yan, Shurong. The study of entrepreneurial quality education in China's Universities and colleges: Advances in Intelligent and Soft Computing[J], Knowledge Discovery and Data Mining, 2012: 93599.

[28] Qi, Yu; Wu, Xiao-Bo; Fan, Xiao-Qing; Xu, Ying Source: 2012 International Symposium on Management of Technology[J], ISMOT, 2012:359-362.

[29] Katok E, Pavlov V. Fairness in supply chain contracts: A laboratory study [J]. Journal of Operations Management, 2013, 31: 129-137.

[30] Leufkens A S, Noorderhaven N G. Learning to collaborate in multi-organizational projects [J].International Journal of Project Management, 2011, 29: 432-441. 
[31] Meng X H, Gallagher B. The impact of incentive mechanisms on project performance [J]. Project management, 2012, 29: 352-362.
[32] Miyaji K, Wang Z, Tanimoto J, Hagishima A, Kokubo S. The evolution of fairness in thecoevolutionary ultimatum games [J]. Collective Behavior and Evolutionary Games, 2013, 56: 13-18. 